\title{
Plant macrofossils from the Czyżów Complex deposits of the Szczerców outcrop, central Poland
}

\author{
Elżbieta Myśkow ${ }^{1}$, Dariusz Krzyszkowski ${ }^{2}$, Lucyna Wachecka-Kotkowska ${ }^{3}$, \\ Dariusz Wieczorek ${ }^{4}$
}

\author{
${ }^{1}$ University of Wrocław, Institute of Experimental Biology; ul. Kanonia 6/8, 50-328 Wrocław, Poland; \\ e-mail: elzbieta.myskow@uwr.edu.pl \\ ${ }^{2}$ University of Wrocław, Institute of Geography and Regional Development; pl. Uniwersytecki 1, 50-137 Wrocław, Poland; \\ e-mail: dariusz.krzyszkowski@ing.uni.wroc.pl \\ ${ }^{3}$ University of Lodz, Department of Geomorphology and Palaeogeography; ul. Narutowicza 88, 90-139 Łódź, Poland; \\ e-mail: lucyna.wachecka@geo.uni.lodz.pl \\ ${ }^{4}$ Geoconsult Sp. z o.o.; ul. Jurajska 6/40, 25-640 Kielce, Poland; \\ e-mail:wieczorek@geoconsult.kie.pl
}

(C) 2016 Authors. This is an open access publication, which can be used, distributed and reproduced in any medium according to the Creative Commons CC-BY 4.0 License requiring that the original work has been properly cited.

Received: 28 September 2016; accepted: 10 December 2016

\begin{abstract}
The paper presents the results of research into the plant macrofossils found in the tectonic Kleszczów Graben, within Mesopleistocene sandy sediments. A number of samples were collected at eight locations from river sediments containing variously sized fragments of plants, mostly from greenish sands overlying Neogene sediments.

The structural characteristics of the sediments show a cyclic record of the formation of point bars, their washing out at supercritical conditions, and their aggradation by fine-grained material during flow waning. Based on lithological and structural studies, it has been demonstrated that the sands accumulated in an environment of a meandering river, whose valley bottom was covered with fairly dense vegetation, inhibiting the influx of mineral material to the floodplain from the surroundings - the valley or glacial plateau slopes. The aim of further analysis was to identify the plant genera of the individual macrofossils (about 40 specimens). The most numerous macrofossils were observed in the middle layers of the profile, within sandy megaripple structures, where mostly fragments of Fraxinus and Acer wood were present. In other layers, several fragments of Pinus and three pieces of Populus wood were identified. Additionally, young stems of dicotyledonous plants and fragments of rhytidome (the outer bark of a tree) were found. The results are discussed in combination with considerations on the deposition of the Czyżów Complex in the Bełchatów outcrop, and on the occurrence of local flora.
\end{abstract}

Keywords: fluvial sediments, plant macrofossils, Holsteinian, Czyżów Complex, central Poland

\section{INTRODUCTION}

Analyses of fossil floras which are essential for biostratigraphic schemes are based largely on palynological studies. However, as far as possible, analyses of plant macrofossils preserved in sediments are carried out simultaneously. These studies concern in particular fruits and seeds but also fragments of stems or roots, especially those with a secondary structure, with well-preserved secondary wood. Analyses of macrofossils are important because their presence may indicate that the material is of local origin (Pyszyński 1991, Pyszyński \& Krzyszkowski 2011).

Interesting features of this type have been earnestly sought in sediments of warm periods of 
the Pleistocene. Good places for this are Europe's deepest outcrops in Bełchatów and Szczerców, which are located in the Kleszczów Graben, central Poland. The Kleszczów Graben is a longitudinal tensional structure formed along pre-existing (Variscan) fault zones as a result of compensation movements in the foreland of the Alpine folding zone (Krzyszkowski 1990). The structural setting of the graben is disturbed by the Dębina salt dome composed of Zechstein deposits (Krzyszkowski 1992). The Bełchatów outcrop is located east of the dome, and the Szczerców outcrop occurs to the west (Fig. 1).

The onset of mining operations in 2002, which included the removal of the overburden of mostly Quaternary deposits in the outcrop of the Szczerców field, and later lignite extraction from 2007, help Quaternary geologists making a preliminary correlation of genetically and temporally similar deposits with those from the geological section of the Bełchatów field. These correlations become more complete as more deposits containing organic remains are studied.
Studies of the pollen of fossil floras in Quaternary deposits of the Bełchatów outcrop have been the basis for their stratigraphic subdivision (Janczyk-Kopikowa 1982, 1985, 1987, Krzyszkowski \& Kuszell 1987, Kuszell 1991a, 1991b, Krzyszkowski 1991a, 1992b, 1992, 1996, Balwierz et al. 2006, 2008). In turn, plant macrofossils found in this outcrop in a number of non-glacial formations - Szerokie, Piaski, Chojny, Czyżów and Łękińsko (Tab. 1), studied and described by Pyszyński (1991) and Pyszyński \& Krzyszkowski (2011), have become an important supplementary element.

The new outcrop of Szczerców is located about $15 \mathrm{~km}$ to the SW of Bełchatów in the western part of the Kleszczów Graben (Fig. 1). The Bełchatów outcrop is located in its eastern part. Studies of the Quaternary deposits are more advanced in the Bełchatów outcrop (Krzyszkowski 1992), although preliminary investigations in the Szczerców outcrop substantiate the previously established stratigraphic scheme (Wieczorek et al. 2015). Some differences that appear do not disturb this scheme, but are rather supplementary elements.

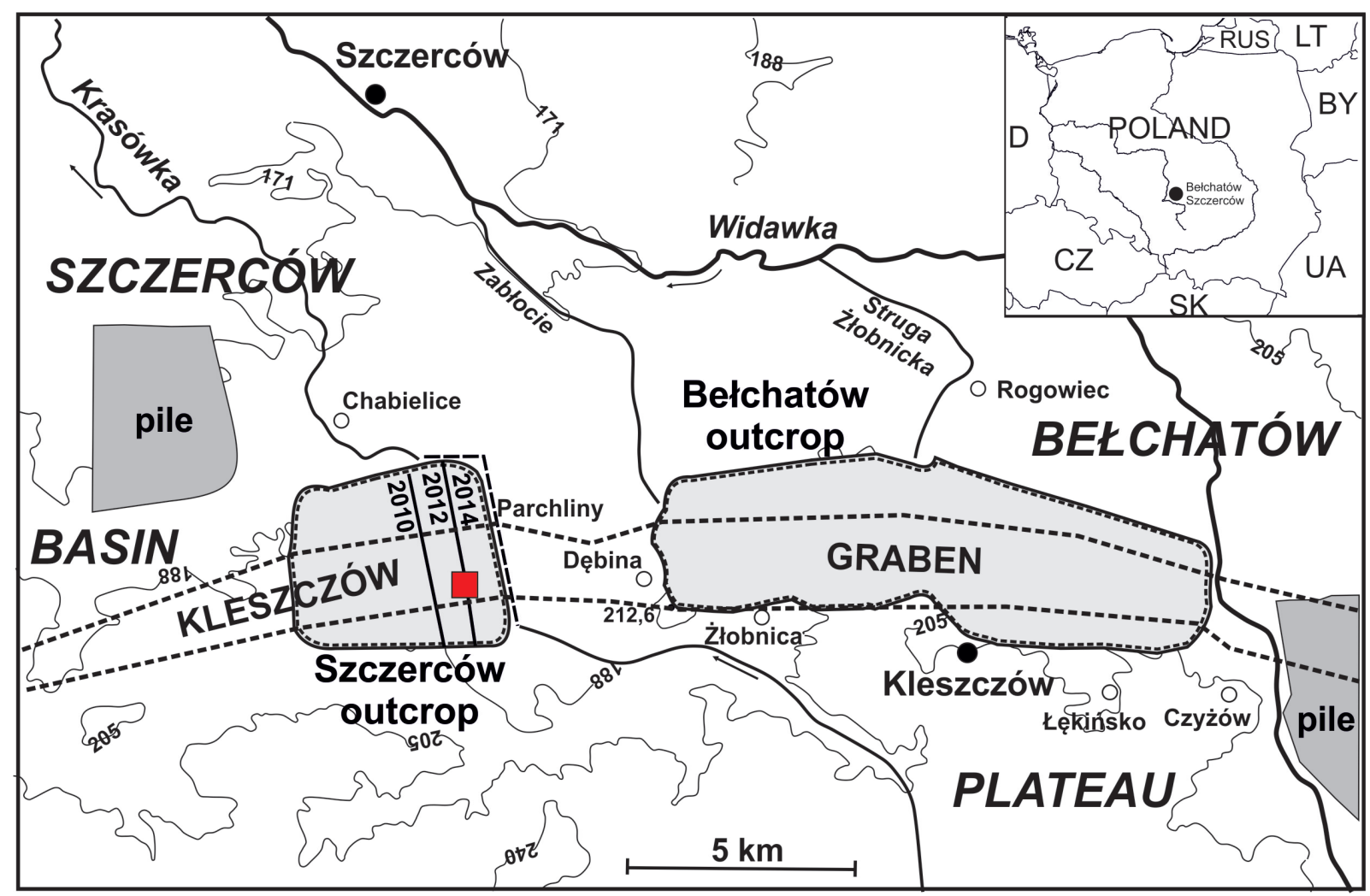

Fig. 1. Location of the study area on a sketch map of the Kleszczów-Szczerców vicinity; red square - profile and section studied in April 2012 (for details see Figs. 2 and 3) 
Table 1. Simplified Pleistocene lithostratigraphic scheme in the Bełchatów and Szczerców outcrops, and the chronostratigraphy after: Krzyszkowski (1996), Krzyszkowski \& Allen (2008); modified and simplified; lithostratigraphy - glacial formations are marked in grey

\begin{tabular}{|c|c|c|c|c|}
\hline Tectonic units & \multicolumn{3}{|c|}{ Lithostratigraphy } & Chronostratigraphy \\
\hline \multirow{5}{*}{ 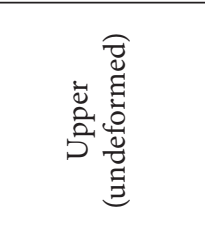 } & Widawka Formation & Szerokie & & Holocene \\
\hline & \multicolumn{3}{|c|}{ Piaski Formation } & Vistulian \\
\hline & \multicolumn{3}{|c|}{ Aleksandrów Formation } & Eemian \\
\hline & \multicolumn{3}{|c|}{ Rogowiec Formation } & Wartanian \\
\hline & \multicolumn{3}{|c|}{ Chojny Formation } & Pilician \\
\hline \multirow{11}{*}{ 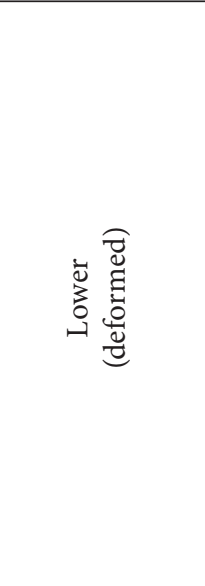 } & \multicolumn{3}{|c|}{ Stawek Formation } & $?$ \\
\hline & \multicolumn{3}{|c|}{ Ławki Formation } & Odranian \\
\hline & \multicolumn{3}{|c|}{ Rokity Formation } & $?$ \\
\hline & \multicolumn{3}{|c|}{ Podlesie Interstadial } & \multirow{4}{*}{$\begin{array}{l}\text { Czyżów } \\
\text { Complex }\end{array}$} \\
\hline & \multicolumn{3}{|c|}{ Czyżów Interstadial } & \\
\hline & \multicolumn{2}{|c|}{$\begin{array}{l}\text { Mazovian } \\
\text { Interglacial }\end{array}$} & $\uparrow$ & \\
\hline & \multicolumn{2}{|c|}{$\begin{array}{l}\text { Ferdynandovian } \\
\text { Interglacial }\end{array}$} & $\downarrow$ & \\
\hline & \multicolumn{3}{|c|}{ Kuców Formation } & Sanian \\
\hline & \multicolumn{3}{|c|}{ Folwark Formation } & Nidanian \\
\hline & \multicolumn{3}{|c|}{ Łękińsko Formation } & Lower Pleistocene \\
\hline & \multicolumn{3}{|c|}{ clay-sand complex } & Upper Miocene - Pliocene \\
\hline
\end{tabular}

The Szczerców outcrop has not yielded such well-documented palynologically deposits yet. Besides an expert report prepared for updating the Detailed Geological Map of Poland, 1: 50,000, Szczerców map sheet (Kuszell \& Iwanuś 2012), the only contribution is the paper by Wachecka-Kotkowska et al. (2016), showing a multiproxy analysis of the Eemian (Aleksandrów Formation) and Vistulian (Wiechselian, Piaski Formation). During documentation work in the Szczerców outcrop, fragments of secondary wood were acquired from the sediments of younger formations. The macrofossils found in these sediments were analyzed and described by Wachecka-Kotkowska et al. (2016).

The study was focused on plant macrofossils of different sizes and their degree of preservation, present within sandy deposits accumulated in a fluvial environment during a Mazovian Interglacial period understood by Krzyszkowski (1992, 1996) as the Czyżów Complex (Tabs. 1, 2).

The Czyżów Complex is represented by sandy, muddy and organic deposits of fluvial and lacustrine origin, with well-developed erosional boundaries (Krzyszkowski 1991a, 1991b, 1992). Deposits of this formation have a greenish tinge. The Czyżów Formation is subdivided into six sets of segments (A-F) (Tab. 2). Segment A was found at the top of the formation, underlain by a set of segments C. Segment B, and the sets of segments D, E and $F$ occurred beneath the set of segments $C$, but their position relative to each other has not been established because they were found as isolated occurrences (Krzyszkowski 1992, 1996). Palynological studies of the organic deposits show that two of the segments had features of interstadials and occurred in the upper part of the section, described as the Podlesie and Czyżów Interstadial (Tabs. 1, 2). The next two segments had features of interglacials (Mazovian and Ferdynandovian Interglacials); however, their mutual time relationship has not been fully explained (cf. Krzyszkowski 1992, 1996, Allen \& Krzyszkowski 2008).

The main aim of the present research was to identify the plant genera of the macrofossils, differing in size and degree of preservation, found in fluvial deposits accumulated during the interglacial period understood by Krzyszkowski (1992, 1996) as the Czyżów Complex. These deposits occur in the western part of the Kleszczów Graben, and are exposed in the Szczerców outcrop. Sedimentological analysis and lithogenetic interpretation of these deposits are also discussed. 
Table 2. Lithostratigraphy and chronostratigraphy of the Czyżów Formation deposits in the Bełchatów and Szczerców outcrops after: Krzyszkowski (1996), Krzyszkowski \& Allen (2008), modified

\begin{tabular}{|c|c|c|c|c|c|c|c|c|}
\hline \multicolumn{7}{|c|}{ Lithostratigraphy } & $\begin{array}{c}\text { Bełchatów \& Szczerców } \\
\text { outcrops }\end{array}$ & Chronostratigraphy \\
\hline \multicolumn{5}{|c|}{ CZYŻOW FORMATION } & \multicolumn{2}{|c|}{$\mathbf{A}$} & Podlesie Interstadial & \multirow{7}{*}{ CZYŻÓW COMPLEX } \\
\hline & & & & & \multirow[t]{3}{*}{$\mathrm{C}$} & $\mathrm{a}$ & & \\
\hline & & & & & & $\mathrm{b}$ & Czyżów Interstadial & \\
\hline & & & & & & c & & \\
\hline \multirow[t]{3}{*}{$\mathbf{F}$} & \multirow[t]{2}{*}{ a } & & $\mathbf{D}$ & $\mathrm{a}$ & \multirow[t]{3}{*}{$\mathrm{E}$} & $\mathrm{a}$ & Mazovian Interglacial & \\
\hline & & B & & $\mathrm{b}$ & & $\mathrm{b}$ & $?$ & \\
\hline & $\mathrm{b}$ & & & c & & c & $\begin{array}{c}\text { Ferdynandovian } \\
\text { Interglacial palaeosol? }\end{array}$ & \\
\hline
\end{tabular}

\section{MATERIALS AND METHODS}

Fluvial deposits of the Czyżów Formation were examined in April 2012 (Fig. 1). They were exposed at mining level II of the Szczerców outcrop $\left(59^{\circ} 13^{\prime} 47.9^{\prime \prime} \mathrm{N}, 29^{\circ} 08^{\prime} 27^{\prime \prime} \mathrm{E}\right)$, on the eastern wall (Fig. 2).

The fieldwork included lithological analysis of the deposits according to the method proposed by Tucker (1996), as well as routine structural examinations (e.g. Krzyszkowski 1992). The lithofacies coding systems of Miall (1978) and Krzyszkowski (1996) were used to describe the lithofacies types. The layers and the location of macrofossils within them have been documented. A geological cross-section of the walls at mining levels I and II, a detailed sketch of exposed deposits, and a photographic documentation have been made.

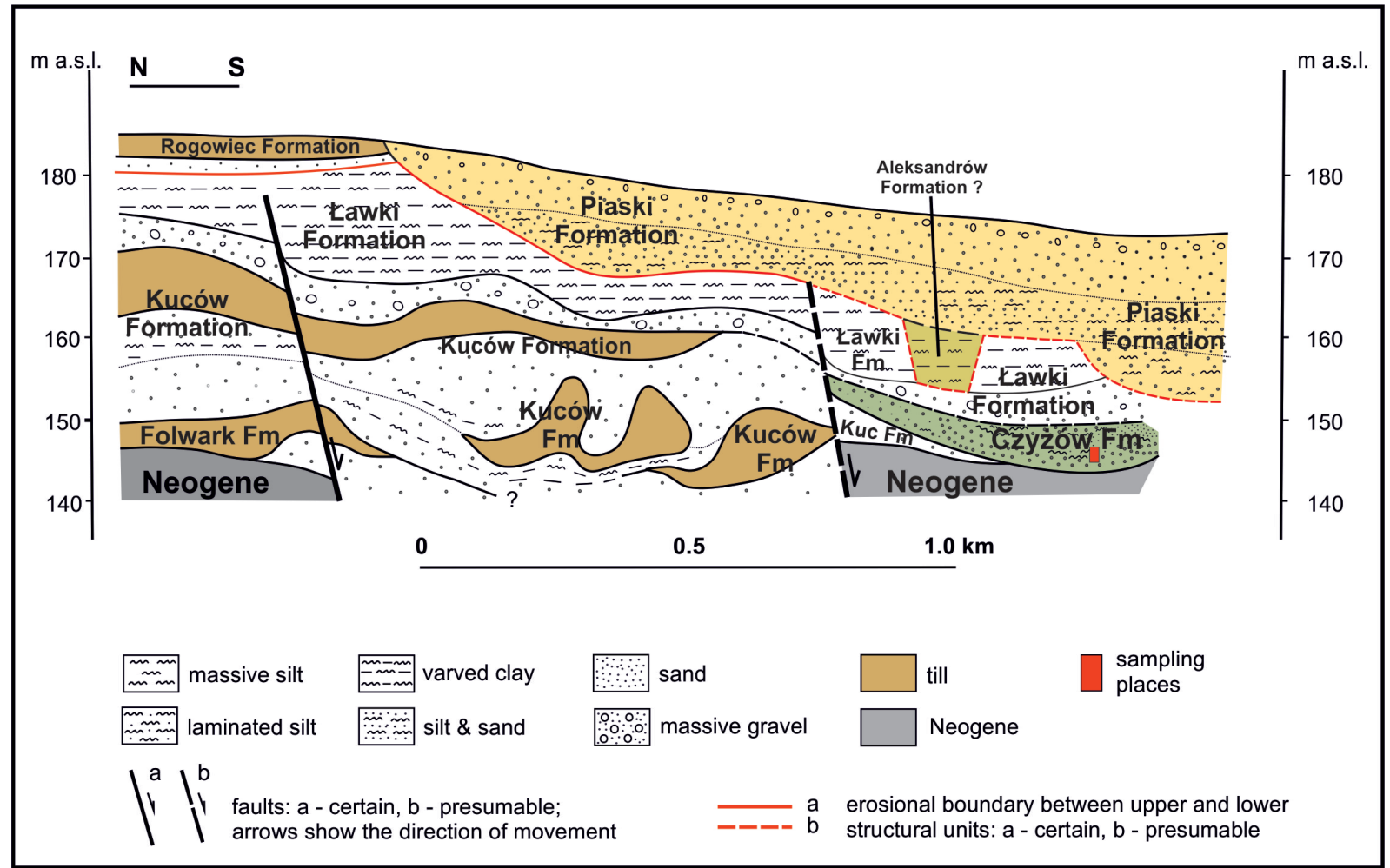

Fig. 2. Sketch of the geological cross-section of the Quaternary sediments within the eastern part of the Szczerców outcrop (near Parchliny) in April 2012 (for details see Fig. 3) 
Soil samples (Nos. 232-239) containing macrofossils were collected at eight locations from variously grained sands (Fig. 2). The most frequent and common material, although difficult to examine, was organic detritus that has not been taken into consideration in microscopic analysis because the material was highly disintegrated. First, soil samples were sifted in order to find all, even minor, macrofossils. Then, if needed, macrofossils (or their minor fragments) were left in the mixture of glycerol and ethanol 100\% (1:3) for a few days to soften the hard tissue (Myśkow 2010, Myśkow \& Zagórska-Marek 2013). To identify the plant genera, transverse, radial and tangential hand-made sections were cut using the razor blade. To examine anatomical (diagnostic) details of macrofossils, the sections were examined in a microscope Olympus BX50 and documented with use of an Olympus Camera DP71 cooperating with a Cell B Software (Olympus Optical Co., Poland). Greguss $(1945,1955)$ and Schweingruber $(1978,1990)$ keys as well as a Website: InsideWood 2004 were used for the identification of wood genera. The terminology was based on IAWA list of macroscopic features for hardwood and softwood identification (IAWA Committee 1989, 2004). The digital images were processed with Macromedia Fireworks MX2004.

\section{RESULTS}

The sandy and sand-muddy deposits which contain large fragments of plant macrofossils were observed in the lower part of a deformed tectonic unit (see Tab. 1). They were mainly covered by $\mathrm{Ne}$ ogene rocks (sands and greenish clays) in a palaeodepression. Both these series were separated by an erosional boundary. Locally, the Czyżów Formation sands overlay the Kuców Formation sands (Figs 2,3). In the upper part of the section they were erosionally cut, and the depression was filled with an ice-dammed lake clay-mud series, a glaciofluvial sand series of the Lawki Formation, and a mud series with peat and gyttja of the Aleksandrów Formation (Eemian). The whole of it is covered by fluvial sandy and sand-muddy deposits of the Piaski Formation (Vistulian). The Czyżów
Formation deposits were found at a depth of 146$156 \mathrm{~m}$ a.s.l., i.e. $28-18 \mathrm{~m}$ b.g.l. They were observed over a distance of more than $600 \mathrm{~m}$. The thickness of the exposed series was estimated at approximately 10 meters.

The Czyżów Formation was represented predominantly by brownish-grey-greenish mediumand coarse-grained sands (Fig. 4). They were also accompanied by other sediments, as mud. Considering the lithology and its variability, it can be supposed that the sands represent a set of segments $\mathrm{C}(\mathrm{Ca}-\mathrm{Cb}-\mathrm{Cc})$ correlated with the Czyżów Interstadial (unfortunately, no palynological studies are available).

At the top of segment Ca there were medium- and coarse-grained sands with horizontal stratification (Sh), and local muds with low-angle cross stratification (Fl) (Fig. 3). They were underlain by trough cross-stratified coarse- and medium-grained sand (St) with telmatic mud, clayey to sandy, black to grey $(\mathrm{Cm})$, and brown to light brown silts with dispersed allochthonous organic detritus (Ca), included in segment $\mathbf{C b}$ (Fig. 3). This segment contained plant macroremains, mainly secondary wood (eight samples for analyses were collected from these deposits). The series is terminated by deposits of segment $\mathbf{C c}$, sands and gravels, e.g. coarse- to medium-grained sand or pebble sand or coarse- to medium-grained sand with trough cross stratification (St) (Fig. 4). They showed a certain repetitiveness of the sequence, as emphasized in Figure 3.

Analyses of eight soil samples from the Szczerców outcrop revealed the presence of wood macrofossils in five of them (Nos. 232, 235, 236, 237 and 239). The wood remains (totally about 40 specimens) differed in sizes; from the very small, not exceeding $0.5 \mathrm{~cm}$, to the relatively large, up to $15 \mathrm{~cm}$ in length. Regardless of the size, they were considerably compressed (Fig. 5A) making the identification of wood genera difficult. In the analyzed materials, both gymnosperm (Fig. 5) and angiosperm (Fig. 6A-I) wood remains were identified. Additionally, fragments of very young dicotyledonous stems with the primary structure, as well as fragments of rhytidome, i.e. the outer bark of the tree (Fig. 6J), were found. 


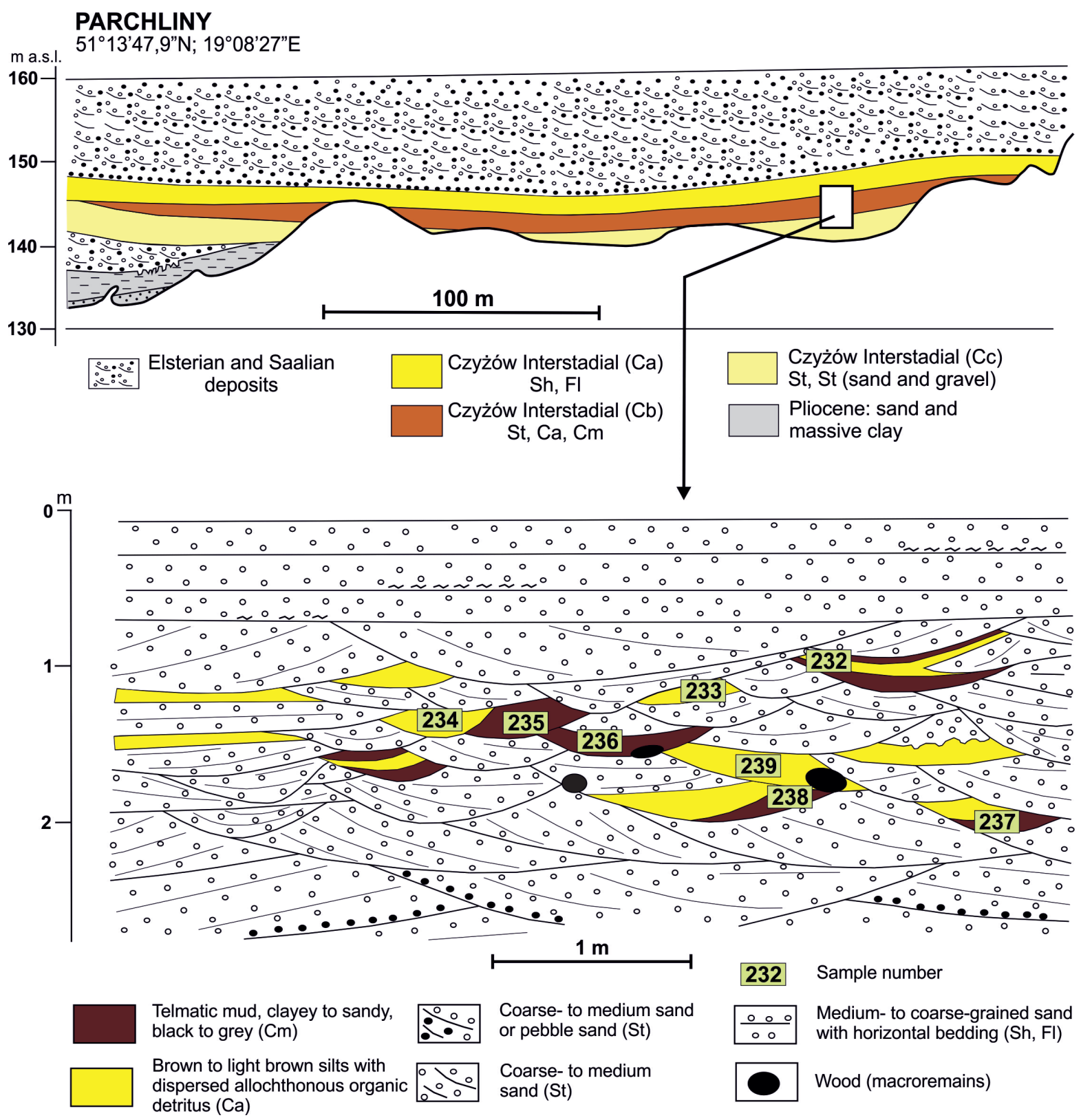

Fig. 3. Sediments of the Czyżów Formation. For explanation of segment $\mathrm{C}(\mathrm{Ca}, \mathrm{Cb}, \mathrm{Cc})$ see Table 2. Symbols and description of lithofacies: St - trough cross-stratified sand, Sh - horizontally laminated sand, Fl-fine-grained sand, clay, horizontally laminated or ripple-cross laminated mud

The spatial distribution of identified macrofossils was related to sediment strata. In the lowest layer, located at a depth of $23.5 \mathrm{~m}$ b.g.l. (sample No. 239), three fragments of Pinus sp. (pine), three of Populus (poplar), and one piece of Acer (maple) wood were found. Besides the wood macrofossils, two fragments of rhytidome and young stems of dicotyledonous plants were identified in this soil sample. Sample No. 237 (23 m b.g.l.) contained only one small fragment of a young stem of a dicotyledonous plant and a fragment of 2-year-old stem, most likely of the poplar. The most numerous and well-preserved plant macrofossils occurred in the central part of the profile (sample No. 236; $22.4 \mathrm{~m}$ b.g.l.). In this layer, more than 20 specimens were found. The majority of them (80\%) were identified as Fraxinus (ash) wood, whereas the remaining 20\% as Acer. The ash wood was also found in all 12 analyzed wood remains in sample No. 235. At the top of the analyzed sequence, at a depth of $21.5 \mathrm{~m}$ b.g.l. (sample No. 232), three larger and few smaller fragments of wood, identified as Pinus were present. 

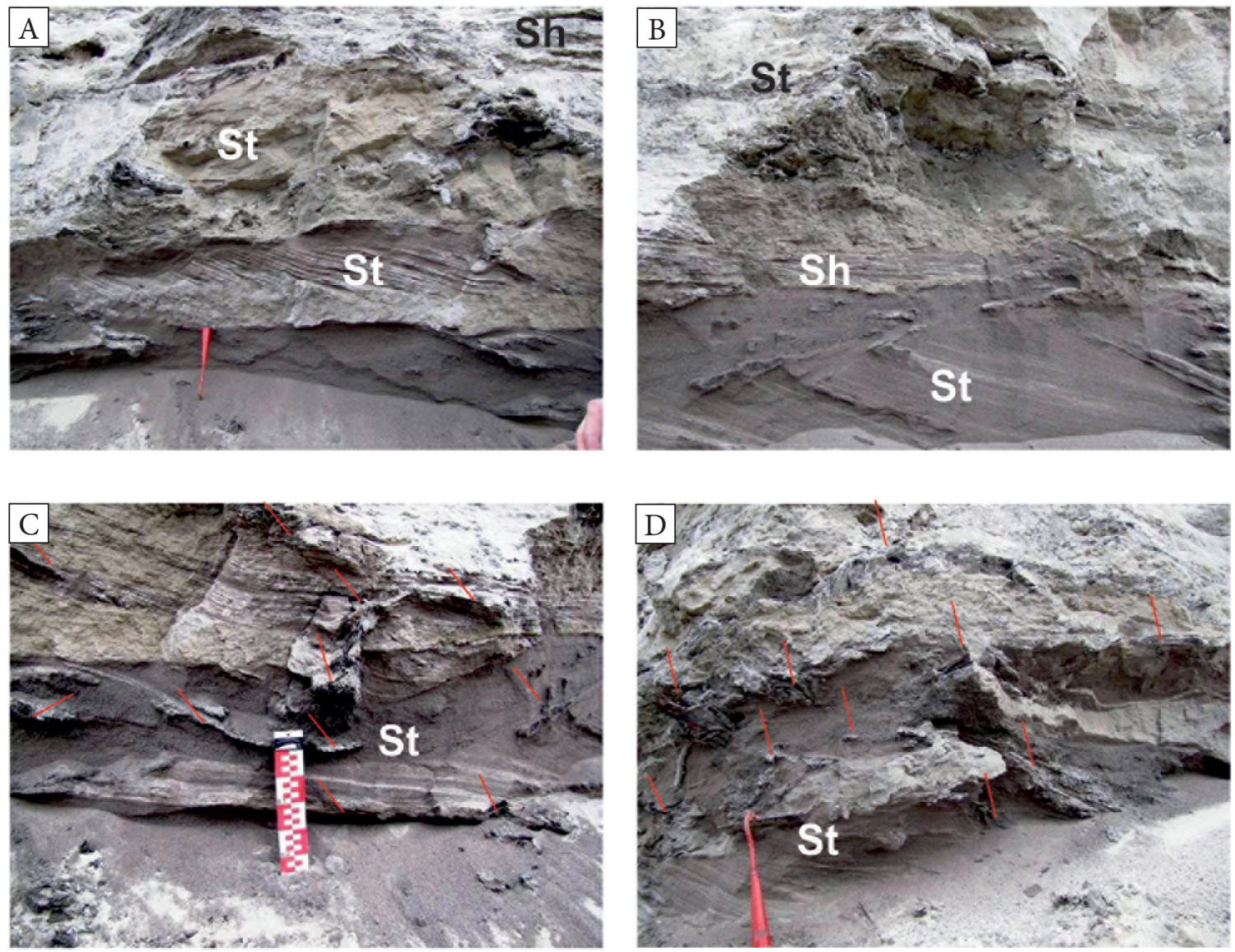

Fig. 4. Photos of sediments of the Czyżów Formation: A), B) medium - to coarse-grained sand (St); C), D) plant macroremains (arrowed)
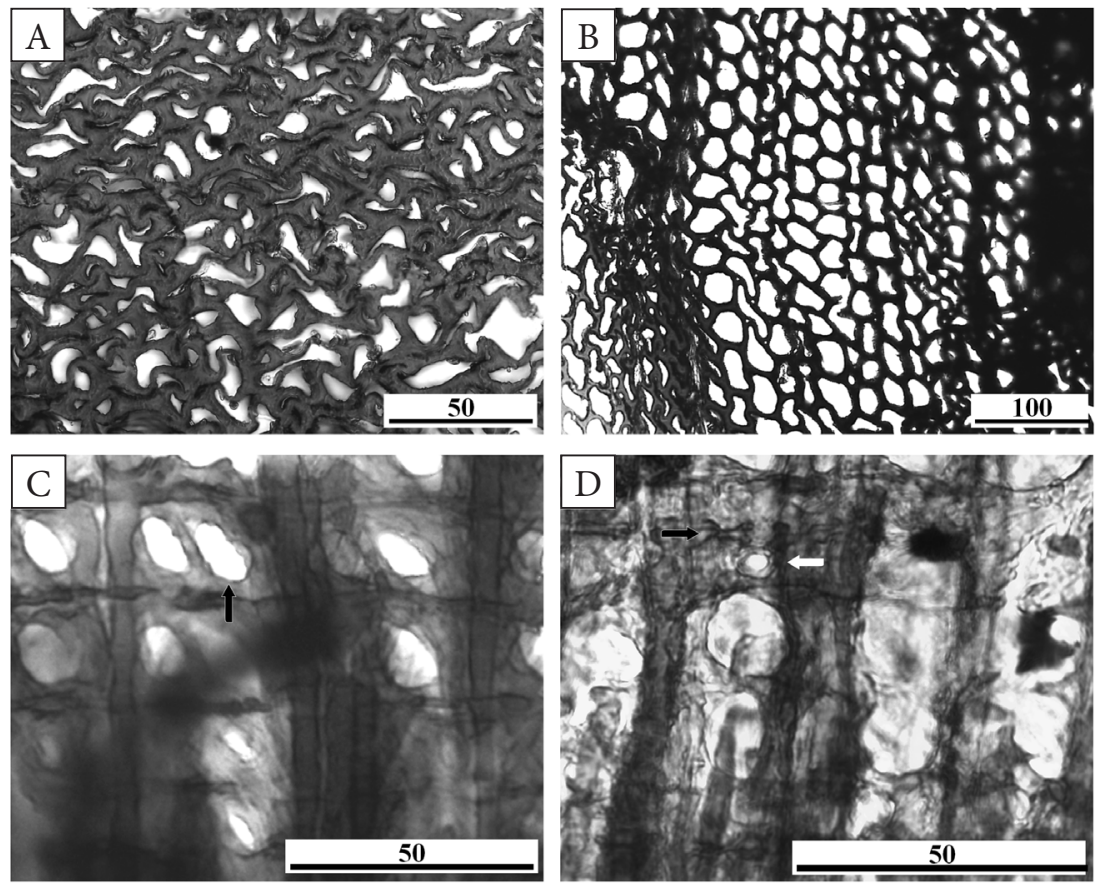

Fig. 5. Fossil wood of Pinus shown on the hand-made sections: $A), B$ ) transverse sections: $A$ - compressed wood, $B$ - typical arrangement of tracheids; C), D) radial sections: $C$ - fenestriform pits between parenchyma cells of the ray and axial tracheids (arrow), $D$ - dentate cell walls (black arrow) and bordered pit (white arrow) of ray tracheids. Bar in micrometres 

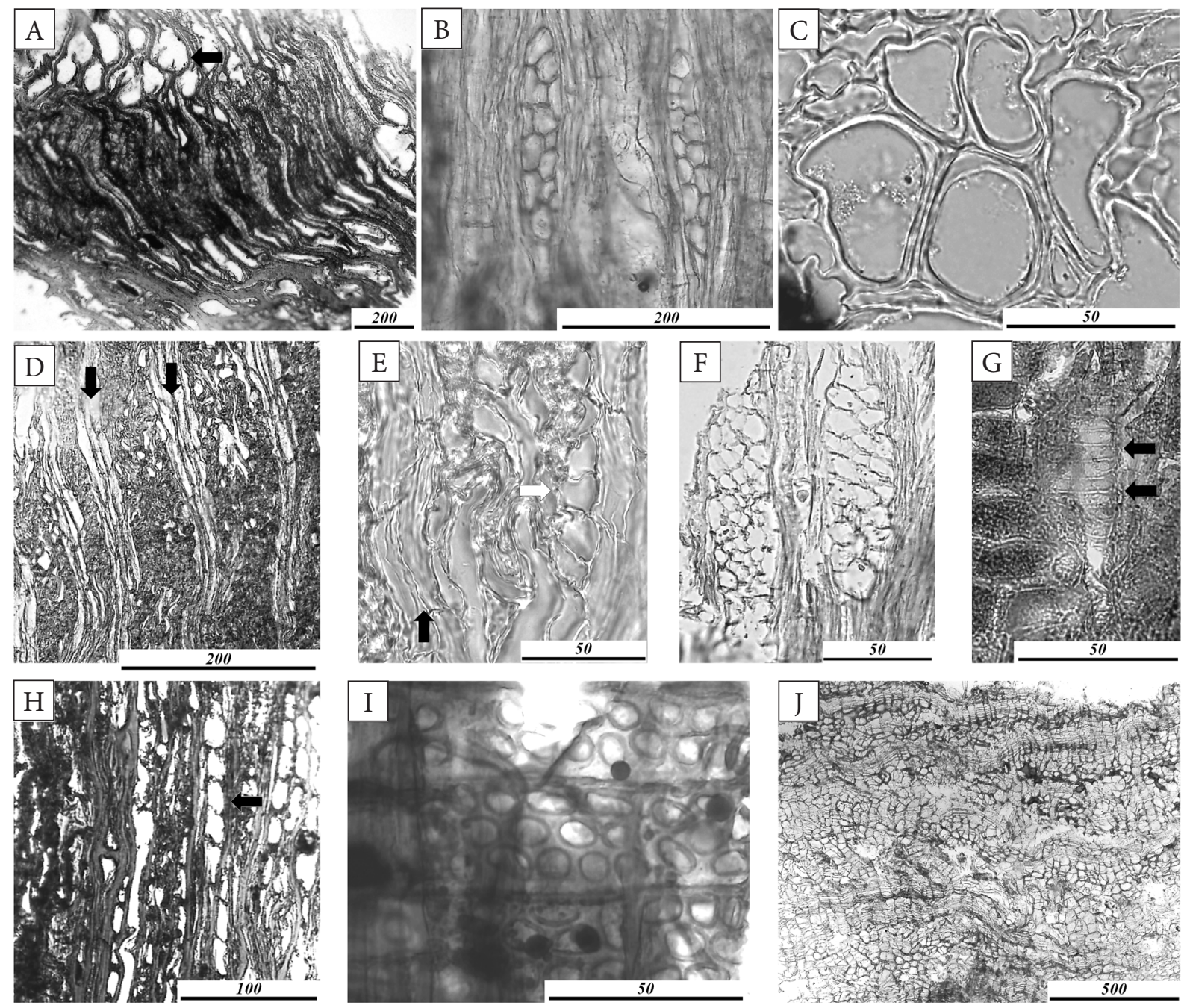

Fig. 6. Macrofossil remains shown on the hand-made sections; A)-C) Fraxinus fossil wood: A - ring-porous wood on transverse section, early-wood vessels denoted by arrow, B-2-3-seriate rays on tangential section, $C$ - latewood vessels with thick secondary cell walls on transverse section; D)-G) Acer wood: $D$ - diffuse-porous wood with thick rays (arrows) on transverse section, $E$ - vessels in radial files (white arrow) and rays (black arrow) on transverse section, $F-3$-5-seriate rays on tangential section, $G$ - distinct spiral thickening of vessels (arrows) on radial section; $H$ ), I) Populus wood: $H$ - uniseriate rays visible on the tangential section (arrow) despite significant compression of tissue, I - large, simple pits between parenchyma cells and vessels on radial section; J) fragment of rhytidome. Bar in micrometres

As mentioned above, both gymnosperm and angiosperm wood fragments were identified in the analyzed profile. Only one genus of gymnosperms, i.e. Pinus was identified. Pinus is characterized by softwood (Fig. 5A, B) with thin-walled epithelial cells of longitudinal and transverse resin canals (Greguss 1955, Schweingruber 1978, IAWA Committee 2004). However, due to significant compression, the wood structure was not well preserved in material examined (Fig. 5A), and on the vast surface of the transverse and tangential sections was almost unidentifiable, including the presence or absence of the resin canals, with thin-walled epithelial cells. The typical wood structure was visible only on the small fragments of these sections (Fig. 5B), but together with better preserved radial sections, the identification of the wood remnants was possible. The most significant diagnostic feature, characteristic only of pine wood, is the presence of large fenestriform pits (Greguss 1955, Schweingruber 1978, IAWA Committee 2004). This type of pits was distinct on the radial sections, unquestionably identifying the wood remnants (Fig. 5C). Therefore, all macrofossils having this type of pits were identified as Pinus wood. In addition, rays in Pinus are 
heterocellular, i.e. they are composed of parenchyma cells and tracheids, in which the bordered pits occur (Fig. 5D). Additionally, in some species, ray tracheids can be characterized by the dentate cell walls (Fig. 5D) That feature was distinct in all gymnosperm wood fragments in sample No. 239; less distinct dentate cell walls were visible in all macrofossils in sample No. 232.

Apart from gymnosperms, the wood fragments of deciduous trees, represented by Fraxinus, Acer and Populus, were also identified in the studied material. The majority of angiosperm wood remains were characterized by the presence of the ring-porous wood (Fig. 6A). Despite the plant material was compressed, especially in the region of latewood, the ring-porous structure of the wood was visible in some places. The thick-walled vessels were distinct and arranged in radial, mostly twocelled rows (Fig. 6B). Additionally, the occurrence of bi- or triseriate rays (Fig. 6C) specified these wood remains as the genus Fraxinus. The macrofossils were determined as Acer based on the following anatomical features: diffuse-porous wood with vessels arranged solitary or in radial rows of 2-4 (Fig. 6D and E); rays 2- to 4-seriate (Fig. 6F), vessels with simple perforation plates and distinct spiral thickenings (Fig. 6G). The wood of Populus is diffuse-porous, with radial rows of 2-4 vessels with simple perforation plates and uniseriate (Fig. $6 \mathrm{H}$ ), homocellular rays (Fig. 6I). Rays were identified as homocellular when the marginal cells of rays had large, simple pits between parenchyma cells and vessels, with 2-4 pits in height (Fig. 6I).

\section{DISCUSSION}

The wood remains were found in deposits with some structural features (see legend in Fig. 3). The cyclic lithofacies succession $\mathrm{St},(\mathrm{Sl}) \rightarrow \mathrm{Sh} \rightarrow \mathrm{Fl}$ may in dicate a record of initial forms of a point bar during normal, relatively low-energy flows, alternately with deposition under the plane-bed phase of the upper flow regime in a meandering river environment (Krzyszkowski 1991a, 1991b, 1996, Zieliński 2014). Lithofacies St correspond to megaripples migrating along the riverbed. Lithofacies Sh indicate deposition of material under conditions of the plane-bed phase of the upper flow regime and during washing out of megaripples.
Lithofacies $\mathrm{Fl}(\mathrm{SFr}(\mathrm{c}))$ prove the deposition of sand material on the underwater part of a point bar (Miall 1978). The low inclination angle of laminae and small ripple marks $\operatorname{Sr}(\mathrm{c})$ are the result of currents transporting the material up the slope of the point bar in a sand-bed meandering river, while muds and sandy muds of lithofacies Fm indicate calm sedimentation due to the free fall of grains on the point bar slope (Krzyszkowski 1996, Zieliński 2014). Based on the lithofacies characteristics, we can infer about a cyclic record of the formation of meandering point bars, their washing out under supercritical flow conditions, and their aggradation by fine-grained material during flow waning.

Macroremains were found mainly in the sediments of lithofacies St and $\mathrm{Fl}(\mathrm{Sr})$ that characterize more energetically stable depositional conditions within the river channel. They are hardly observed in the horizontally stratified sands of Sh, deposited under the upper flow regime or at the transition from the lower to the upper regime. It may prove that the macroremains have not been significantly redeposited. This view is supported by their common occurrence and a large accumulation of tree trunks and branches of various sizes, which were observed during documentation work. Large macrofossils, over $1 \mathrm{~m}$ in size, could not be brought by a river flowing under supercritical flow conditions (Miall 1978). Therefore, likely, macrofossils analyzed here were directly formed and deposited as "parautochthonous" and they could be compared to those from the nearby located well-documented Bełchatów outcrop (Pyszyński 1991, Pyszyński \& Krzyszkowski 2011).

In terms of their lithostratigraphic position, the studied sands show a similarity to the Czyżów Complex sediments, found in the nearby Bełchatów outcrop and deposited during the Mazovian (Holsteinian?) Interglacial. Their position in the geological succession was also similar. The difference is that the only set of units described from the Czyżów Complex in the Szczerców outcrop was the $\mathrm{C}$. This may result from the greater reduction of sediments due to exogenous processes in this part of the Kleszczów Graben. It seems that ice lobes of the Scandinavian ice sheet, advancing from the west, exerted a greater destructive force (Krzyszkowski et al. 2015). 
Like in the Bełchatów outcrop, within all examined non-glacial sediments, the macrofossils were best preserved in the sands, and less well preserved in the muds of the Czyżów Formation (Krzyszkowski 1991b, Pyszyński 1991, Pyszyński \& Krzyszkowski 2011). Their relatively small number (totaling about 40 macrofossils) does not reflect the vegetation of the stand (Pyszyński 1991). However, taking together the results of the macrofossil and pollen analyses, as well as regarding the local origin of macrofossils, it makes it possible to draw broader conclusions on the climate and flora of the analyzed period. Unfortunately, due to the lack of pollen analysis for the sediments of the Czyżów Formation from the Szczerców outcrop, our results can be compared only to the similar analysis for the Bełchatów outcrop. According to the palynological analysis (Kuszell 1991b), the highest percentage of tree pollen grains was achieved for Pinus, Picea and Alnus, whereas the participation of other tree genera, i.e. Betula, Quercus, Ulmus and Corylus, was lower, and pollen grains of Juniperus, Larix, Salix, and Fraxinus were only sporadically present. Such pollen spectra show that the climatic optimum was characteristic of the deciduous forest of interstadial episode (Kuszell 1991b). Pyszyński (1991) and Pyszyński \& Krzyszkowski (2011) confirmed the local deposition of macrofossils of Pinus sylvestris and Alnus, whose pollen grains dominated in the whole profile (Kuszell 1991b). Additionally, a well-preserved Juniperus fossil wood was identified, despite the lack of pollen of this genus in this level of the profile (Kuszell 1991b, Pyszyński 1991). During the present analysis, fragments of pine wood were also found. The presence of pine wood is unsurprising since the pollen grains of this genus were abundant in the analyzed profile of this formation (Kuszell 1991b). As was mentioned before, the fragments of pine wood with distinct dentate cell walls of the ray tracheids were observed in sample No. 239. This feature is characteristic of a few species of Pinus including Pinus sylvestris (Scotch pine) (Greguss 1955, Schweingruber 1978, IAWA Committee 2004). Regarding the occurrence of Scotch pine macrofossils in the sediments of Czyżów Formation from the Bełchatów outcrop (Pyszyński 1991, Pyszyński \& Krzyszkowski 2011) as well as ecological requirements of this species, it seems likely that the P. sylvestris macrofossils were also observed in our material. Additionally, it is worth noting that only pine wood fragments were found at the top of the profile, which may indicate climate cooling. In contrast, genera of the temperate climate and characterized by the tolerance to the environmental conditions, i.e. Fraxinus, Acer and Populus were found in the middle layers of the profile. Of those, only Fraxinus pollen grains were observed in the Czyżów Formation of the Bełchatów field (Kuszell 1991b), while no macrofossils of these genera were identified (Pyszyński 1991). The presence of Fraxinus wood in the analyzed layers of the profile corresponds well to the genus ecological requirements. Ash is a tree species associated with the riparian forests formed along the bottoms of meandering river valleys, requiring moist and fertile soils (Barzdajn et al. 1995, Tulik 2009). Regarding the tree preferences, its presence in the layers correlates well with the nature of the formation, originated by the meandering rivers. It further confirms that this type of geological formation as well as the type of fossil forest vegetation could arise during a warm period of the Pleistocene, e.g. some part of the Mazovian Interglacial, Czyżów Complex.

\section{CONCLUSIONS}

The geological and palaeobotanical investigations carried out for the present study allow us to advance the following conclusions:

1. In the Szczerców outcrop, fragments of vascular plants that can suggest at least interstadial thermal conditions at that time were found in sand sediments of the Czyżów Complex, and precisely the Czyżów Interstadial.

2. The sand sediments were deposited in a meandering river environment, as evidenced by the facies succession. Such a river channel type indicates "pluvial" climate conditions at that time and a dense cover of vegetation hampering the supply of mineral material from the valley slopes into the floodplain.

3. The presence of pine wood at the top of the profile may suggest climate cooling, whereas the genera of the temperate climate, i.e. Fraxinus, Acer and Populus, were found in the middle layers of the profile. 
4. The sand sediments from the Szczerców outcrop which host the plant macrofossils show a high degree of similarity to the sediments representing the set of units $\mathrm{C}$ of the Czyżów Formation in the Bełchatów outcrop. However, it cannot be currently ascertained whether they originated in the same river.

This study was partly performed thanks to grants from the National Fund for Environmental Protection and Water Management for updating the Detailed Geological Map of Poland, 1:50,000 scale, Szczerców map sheet. This work was supported in part by the University of Wroctaw (Grant No. 1068/S/IBE/16). We would like to thank the anonymous reviewers for the extensive revision of the manuscript and their helpful comments which made these improvements possible.

\section{REFERENCES}

Allen P. \& Krzyszkowski D., 2008. Till base deformation and fabric variation in Lower Rogowiec (Wartanian, Younger Saalian) Till, Bełchatów outcrop, central Poland. Annales Societatis Geologorum Poloniae, 78, 1, 19-35.

Balwierz Z., Goździk J. \& Marciniak B., 2006. Palinologiczne i diatomologiczne badania osadów interglacjału mazowieckiego z odsłonięcia w kopalni Bełchatów. Przegląd Geologiczny, 54, 61-67.

Balwierz Z., Goździk J. \& Marciniak B., 2008. Geneza misy jeziornej i warunki środowiskowe akumulacji limniczno-bagiennej $\mathrm{w}$ interglacjale mazowieckim $\mathrm{w}$ rowie Kleszczowa ('środkowa Polska). Biuletyn Państwowego Instytutu Geologicznego, 428, 3-21.

Barzdajn W. et al. (oprac.), 1995. Jesion wyniosty - Fraxinus excelsior. Nasze Drzewa Leśne: monografie popularnonaukowe, 17, Polska Akademia Nauk. Instytut Dendrologii, Kórnik.

Greguss P., 1945. The identification of Central-European dicotyledonous trees and shrubs based on xylotomy. Hungarian Museum of Natural History, Budapest.

Greguss P., 1955. Identification of living gymnosperms on the basis of xylotomy. Akademiai Kiado, Budapest.

IAWA Committee, 1989. IAWA list of microscopic features for hardwood identification: with an appendix on non-anatomical information. IAWA Bulletin, 10, 3, 219-332.

IAWA Committee, 2004. IAWA list of microscopic features for softwood identification. IAWA Journal, 25, 1, 1-70.

InsideWood 2004-onwards. [on-line:] http://insidewood.lib. ncsu.edu/search [access: November 29, 2016].

Janczyk-Kopikowa Z., 1982. Flory kopalne rejonu Bełchatowa. [in:] Czwartorzęd rejonu Betchatowa: Przewodnik I sympozjum: Główne kierunki i wstępne wyniki badań $w$ zakresie stratygrafii $i$ struktur osadów, Wydawnictwa Geologiczne, Warszawa, 36-40.
Janczyk-Kopikowa Z., 1985. Analiza pyłkowa osadów z profilu Buczyna II. [in:] Czwartorzęd rejonu Betchatowa: Przewodnik II sympozjum, Państwowy Instytut Geologiczny, Warszawa - Wrocław, 89-91.

Janczyk-Kopikowa Z., 1987. Flory interglacjalne i interstadialne w kopalni Bełchatów. [in:] Czwartorzęd rejonu Bełchatowa: Przewodnik II sympozjum, Państwowy Instytut Geologiczny, Warszawa - Wrocław, 33-35.

Krzyszkowski D., 1990. Litostratygrafia osadów czwartorzędowych w rowie Kleszczowa. Geologia, 16, 1, 111-137.

Krzyszkowski D., 1991a. The Middle Pleistocene polyinterglacial Czyżów formation in the Kleszczów Graben (Central Poland): stratigraphy and palaeogeography. Folia Quaternaria, 61/62, 5-58.

Krzyszkowski D., 1991b. Extra-channel muddy sedimentation and soil formation during the Middle Pleistocene Czyżów Interstadial with examples from the Bełchatów outcrop (Kleszczów Graben, central Poland). Folia Quaternaria, 61/62, 179-214.

Krzyszkowski D., 1992. Czwartorzęd rowu Kleszczowa: litostratygrafia i tektonika: zarys problematyki na podstawie obserwacji w odkrywce KWB "Bełchatów". Acta Universitatis Wratislaviensis. Studia Geograficzne, 54, Wydawnictwo Uniwersytetu Wrocławskiego, Wrocław.

Krzyszkowski D., 1996. Climatic control of Quaternary fluvial sedimentation in the Kleszczów Graben, Central Poland. Quaternary Science Reviews, 15, 315-333.

Krzyszkowski D. \& Kuszell T., 1987. Nowe stanowisko interglacjału ferdynandowskiego w odkrywce Bełchatów. [in:] Czwartorzęd rejonu Betchatowa: Przewodnik II sympozjum, Państwowy Instytut Geologiczny, Warszawa Wrocław, 125-134.

Krzyszkowski D., Wachecka-Kotkowska L., Wieczorek D. \& Stoiński A., 2015. Petrography of glacial tills in the Szczerców Outcrop Central Poland - problems of stratigraphic interpretation. Studia Quaternaria, 32, 2, 99-108.

Kuszell T., 1991a. Ferdynandovian Interglacial in the Bełchatów outcrop. Folia Quaternaria, 61/62, 75-83.

Kuszell T., 1991b. The floral characteristics of the Middle Pleistocene Czyżów Interstadial in the Bełchatów outcrop, Central Poland. Folia Quaternaria, 61-62, 215-22.

Miall A.D., 1978. Lithofacies types and vertical profile models in braided river deposits: a summary. [in:] Miall A.D. (ed.), Fluvial sedimentology, Canadian Society of Petroleum Geologists Memoir, 5, Geological Survey of Canada, Calgary, 597-604.

Myśkow E., 2010. Procambium-cambium transition during vascular meristem development in Diospyros lotus. Botany, 88, 985-993.

Myśkow E. \& Zagórska-Marek B., 2013. Dynamics of the ray pattern in cambium of Diospyros lotus. Dendrobiology, 69, 21-30.

Pyszyński W., 1991. Macroscopic remains of wood from alluvial deposits of the Czyżów Interstadial, Bełchatów outcrop, Central Poland. Folia Quaternaria, 61/62, 223-228.

Pyszyński W. \& Krzyszkowski D., 2011. Makroskopowe szczątki roślinne z czwartorzędowych osadów odkrywki Bełchatów, środkowa Polska. Przegląd Geologiczny, $59,12,785-792$. 
Schweingruber F.H., 1978. Microscopic wood anatomy. Structural variability of stems and twigs in recent and subfossil woods from Central Europe. Swiss Federal Institute of Forestry Research, Birmensdorf.

Schweingruber F.H., 1990. Anatomy of European Woods: An Atlas for the Identification of European Trees, Shrubs and Dwarf Shrubs. Eidgenössische Forschungsanstalt für Wald Schnee und Landschaft Haupt, Bern und Stuttgart.

Tucker M.E., 1996. Sedimentary Rocks in the Field. 2nd ed. Wiley, Chichester.

Tulik M., 2009. Struktura drewna jesionu wyniosłego (Fraxinus excelsior L.) a proces zamierania drzewostanów jesionowych. Sylwan, 153, 10, 662-667.

Wachecka-Kotkowska, Krzyszkowski D., Malkiewicz M., Mirosław-Grabowska J., Niska M., Krzymińska J., MyśkowE.,
Raczyk J., Wieczorek D., Stoiński A. \& Rzodkiewicz M., 2016. An attempt to reconstruct the late Saalian to Plenivistulian (MIS6-MIS3) natural lake environment from the "Parchliny 2014" section, central Poland. Quaternary International [in press]. DOI: 10.1016/ j.quaint.2016.06.013QI.

Wieczorek D., Stoiński A., Krzyszkowski D., Wachecka-Kotkowska L. \& Krzymińska J., 2015. The results of new studies of Quaternary sediments in the Kleszczów Graben, Szczerców Outcrop, Bełchatów Lignite Opencast Mine. Landform Analysis, 29, 63-71.

Zieliński T., 2014. Sedymentologia. Osady rzek i jezior. Wydawnictwo Naukowe Uniwersytetu im. Adama Mickiewicza, Poznań. 